\title{
Barriers to Start-Up the Business among Students at Tertiary Level: A Case Study in Northern States of Peninsular Malaysia
}

\author{
Azyyati Anuar ${ }^{1}$, Ida Normaya Mohd Nasir ${ }^{2}$, Firdaus Abdul Rahman ${ }^{3}$ \& Daing Maruak Sadek \\ ${ }^{1}$ Faculty of Business Management, Universiti Teknologi MARA, Kedah, Malaysia \\ ${ }^{2}$ Faculty of Mathematical Sciences, Universiti Teknologi MARA, Kedah, Malaysia \\ ${ }^{3}$ Faculty of Information Management, Universiti Teknologi MARA, Kedah, Malaysia \\ ${ }^{4}$ Academy of Contemporary Islamic Studies, Universiti Teknologi MARA, Kedah, Malaysia \\ Correspondence: Azyyati Anuar, Faculty of Business Management, Universiti Teknologi MARA, Caw. Kedah, \\ 08400 Merbok, Kedah, Malaysia. Tel: 60-12-553-4339. E-mail: azyyati@kedah.uitm.edu.my
}

Received: April 12, 2013 Accepted: May 30, 2013 Online Published: August 30, 2013

doi:10.5539/ass.v9n11p290

URL: http://dx.doi.org/10.5539/ass.v9n11p290

\begin{abstract}
At university level, students are encouraged and expectant to create an entrepreneurial culture where they need to experience on how to operate the business inside the campus. This was also to aid the university in producing graduates who can help meet the government's aspiration of turning Malaysia into a high-income country. Therefore, students are played a significant role as a novice entrepreneur in order to accomplish Vision of 2020. Generally, we have seen some of the research highlights the importance of entrepreneurship education, the effectiveness of entrepreneurship training and also seen the entrepreneurship has been taught in the class but unlikely, they do not fully utilized the given knowledge to practice it. The objectives of this paper is to identify the barriers faced by students for various departments to start-up the business at the IPTA's in northern region that concise of three variables; personality traits, entrepreneurial skills and micro level. The target population of this study is all students in higher institutions in northern region including UiTM Kedah, UiTM Pulau Pinang, UiTM Perlis, UiTM Perak, USM, UNIMAP and UUM. The expected outcome is to expose a student on how to start-up the business and experiencing the challenges of entrepreneurial environment.
\end{abstract}

Keywords: barriers, business, personality traits, entrepreneurial skills, micro level

\section{Introduction}

Entrepreneurship is not a bizarre subject among Malaysian society where presently most of the Malaysian entrepreneur participating in a various industries and business ventures. Moreover it is one of the government exclamations to achieve developed nation status by 2020 and yet economic growth of 6 per cent a year will be required (PEMANDU).

In this line, The Economic Transformation Programme (ETP) has been built on the direction outlined in the Tenth Malaysia Plan to develop a markedly different approach to delivering the government's objectives. In putting Malaysia on the world map, a comprehensive planning need to be taken critically where all parties including public sector, private sectors, students and fresh graduates have to play their important part in ensuring the ETP's will be succeed and also to make Malaysia to become a high-income nation. It is also supported by Minister of Higher Education, Dato' Seri Khalid Nordin where entrepreneurship will be the key enabler for the country to achieve high income nation status by 2020 and as the players in the entrepreneurial culture will be the main catalyst to the economic transformation.

Being entrepreneur is one of the strategies to achieve the vision of 2020 and it also will help to reduce the number of unemployment rate. Salina, Nurazariah, Noraina \& Jegatheesan (2011), stated a study has been carried out by the Ministry of Higher Education on graduate employability from 2006 to 2009. It has shown in 2006, the unemployment rate among graduates was high at 31 per cent high; in 2007 the unemployed graduate rate had dropped to 27 per cent. Thus, graduate unemployment was still standing at a high 24 per cent in 2008 . Conversely on the news of 7 July 2012, the unemployment rate in Malaysia has dropped from 3.1 per cent to 2.9 per cent in 2012. Deputy Finance Minister Datuk Donald Lim Siang Chai said Malaysia had managed to attract foreign 
investors where the investors are comfortable and confident with the business climate in Malaysia, which is facilitated by programmes endorsed by the Federal Government such as the ETP (Lee Yen Mun, 2012).

However, a prompt action needs to be taken among students at tertiary level to ensure the unemployment rate will be dropped progressively. In order to solve this problem, entire universities should embed an entrepreneurial culture among students though the subjects and courses they take are distinctive. But a spectrum questions will be raised whether business ventures can be considered as a career or it can be taught successfully in the universities (Henderson \& Robertson, 1999).

To start-up the business in the middle of their study required much an effort and undoubtedly will be more pressure for them, except to those who are interested in running a business. Totally it will be an advantage for the students that will make an entrepreneur as a full time career after graduates. Nevertheless, it is not an easy as they thought where the obstacles in running a business cannot be evaded. Sandhu, Sidique \& Riaz (2011), there are many barriers faced by graduates in order to become entrepreneurs and a thorough understanding is needed to formulate effective policies to curb graduate unemployment.

It is therefore important to understand what drives students and graduates to explore self-employment and business start-up, what constraints and enablers are likely to be encountered during the early stages of graduate business start-up, and what support systems can be put place to increase the likelihood of conversion into an established business with growth potential (Smith \& Beasley 2011).

Furthermore although many young people were ambivalent towards entrepreneurship, those from schools in economically-deprived areas viewed entrepreneurs particularly negatively, believing that there were more barriers to entry than for their peers from more efficient areas (Henderson \& Robertson, 1999).

\subsection{Problem Statement}

The students should be moulded as a young entrepreneur so that they are capable to think and not just to vomit what they gather from their lectures and the lecturer's especially Malay students. Our Prime Minister Datuk Seri Najib Tun Razak reminded Malay entrepreneurs to enhance their knowledge because today's world was no longer based on 'technical know who', but 'technical know -how'.

Generally, most of the previous research has examined the challenges, constraints, difficulties, obstacles faced by entrepreneurs of doing a business and has ignored persons who are willing to create a new venture. Hence, the prior research also highlights the importance of entrepreneurship education, the effectiveness of entrepreneurship training, student needs and higher education capability and so on.

As well as the selected respondents also came from the various backgrounds such as businessman, franchaisee, manager and manufacturer but only a few studies focusing on students at the tertiary level to start-up the business. The students have a full set of theories and yet they have an intention to start off the business, but there are a number of barriers that could affect the students to open up the business.

Therefore, the researcher needs to search out either these three factors (personal traits, entrepreneurial skills and micro level) that might hinder the students to start-up the business.

\subsection{Research Objectives}

This study aims to achieve the following objectives:

1) To identify the barriers of personality traits faced by students to start-up the business.

2) To identify the barriers of entrepreneurial skills faced by students to start-up the business.

3) To identify the barriers of micro level faced by students to start-up the business.

\section{Literature Review}

\subsection{Entrepreneurship Education}

Recent studies show that entrepreneurship education does play a significant role in cultivating the entrepreneurship spirit among graduates (Ronstadt, 1987; Katz, 2003; Solomon et al., 2002; Robinson and Hayes, 1991; Sexton and Upton, 1984). Students who have taken a course or major in entrepreneurship have shown greater interest in becoming entrepreneurs and these students act more entrepreneurially than other students in taking up the challenge to start a new business (Kolvereid and Moen, 1997).

The study revealed that education does have an effect in contributing to the formation of entrepreneurship among graduates. We also seen the entrepreneurship has been taught in the class but failed to perform the business practicing in the campus. 


\subsection{Personal Traits}

Minister of Higher Education, Dato' Seri Khalid Nordin on his speech about "Higher Education in the New Economy: Roadmap of Prospects and Challenges", he hoping to see in each graduates have an entrepreneur characteristics such as willing to take risks, resilient, resourceful and innovative which that will take them to succeed in whatever they decide to embark on.

Personality characteristics commonly described and categorized by many writers and researchers is the need for achievement, locus of control, risk-taking, innovative, self-confidence and ambiguity tolerance (Hian 1996; Kinicki \& Williams 2003; Shane 2003; Gurol \& Atsan 2006). Contrast with Cunningham \& Lischeron (1991) who examined the three personality traits in his study consisting of personal values such as honesty, duty, responsibility and ethical behavior, risk taking, and need for achievement.

Definition of the characteristics of successful entrepreneurs presented by Louw et al. (2003) is a) identify business opportunities; b) to design, create and expand for profit organization through time, effort and money; c) mixing creativity, innovation and risk-taking and hard work; d) correcting the suitability of resources. While the study made by Hisrich \& Grachev (1995) on the features of Russian entrepreneurs find themselves a vibrant, independence, competitive and self-confidence.

Based on the above studies, it shows that most of the previous researchers focused on personality traits to become a successful entrepreneur. In this study, researchers used four personality traits that initiatives, problem solving, information seeking and self-confidence to explore whether these aspects contribute to the constraints to start-up the business.

\subsection{Entrepreneurial Skills}

"The ability to sell is the number one skill in business. If you cannot sell, don't bother thinking about becoming a business owner"-Robert Kiyosaki. From this Kiyosaki's statement, it shows that skill is salient things that happen in today's competitive business world. Entrepreneur should possess basic skills to enable to start, develop, finance and market the business enterprise.

There are several studies has been done correlated to business and entrepreneurial skills and specifically about barriers to start-up among students. Giocamin, Janssen, Pruett, Shinnar, llopis \& Toney (2010) has found that lack of financial, lack of knowledge and experience are clearly identified as the barriers to start-up the business among the Indian students compared to the Chinese, Spanish and Belgian students. Research by Robertson et al. (2003) towards the barriers to start-up the business among Metropolitan Leeds University has resulting about 22 percent of students does not have intention to open up the business due to lack of idea or opportunity to put into action. Though they lack of knowledge, but still they have guts and entrepreneurial spirit to make an effort. Giocamin, et al. (2010) had purposed, based on their findings that entrepreneurship education programs in India place an emphasis on the support services available to aspiring entrepreneurs and to strengthen students management skills. Linan (2008) on his research has suggested education and training initiatives trying to increase entrepreneurial potential in the participant should include workshops specifically addressed to the development of those entrepreneurial skills. Thus, if a student started from scratch, small business can be a great source of information and practical experience with respect to running a business and improving the business skills.

According to Cunningham (1996); Ab. Aziz \& Zakaria (2004); Nor Aishah \& Isteti (2006); Lussier (2006), there are three skills that have been identified in carrying out the business: technical skills, conceptual skills and interpersonal skills. From these authors, we decided to choose knowledge and time management as the elements of our research. Knowledge was derived from Cunningham (1996) where he defined technical skills is a knowledge and financial management. Meanwhile time management was pointed out by Wan Liz \& Sulzari (2006). Wan Liz \& Sulzari (2006) stated, it is not just the business idea to ensure the business will be succeed, but also the most important thing is a specific/uniqe skills need to be obtained by every entrepreneur including time manegement. Time management is an ability to manage the time productively, enable to delegate the task based on priority and implementing the task according to schedule (Wan Liz \& Sulzari, 2006).

\subsection{Micro Level}

The literature review has focused on micro-level factors that might hindering students to start-up the business consisting opportunity identification, motivation, resources/financing strategies and performance where (Jamali, 2009) on her study about constraints and opportunities facing women entrepreneurs in developing countries has found the barriers on those micro-level factors except performance. According to Jamali's research, the three most important barriers encountered through their experience, most female entrepreneurs mentioned the balancing of 
work and family life as the first and most important barrier, followed by societal attitudes and access to capital (Jamali, 2009).

Importance of the concept of opportunity as a key to understanding entrepreneurship and economic change has been identified by key authors (Sanz-Velasco, 2006). His study pertaining to opportunity development as a learning process for entrepreneurs has found that resources influence opportunities and their development. Meanwhile on Jamali's research, opportunity identification was one of the barriers for women entrepreneurs to start up a new business and human capital variables (e.g. education and work experience). In this line, the students might face the same problem where the chances to open up a business is everywhere, but how to identify the opportunity will be the next question to be discovered.

The last element of micro level is financial. Regarding on McMillan (2006), the most difficult things for entrepreneur to open up the business is to extract the money and certainly it will be based on the business size. According to Robertson et al. (2003), study has illustrated more than 50 percent student from Leeds Metropolitan University mentioned that financial risk as one of the barrier to open up the business because the students need a security after graduate since they were seeking for a good job. McLarty (2005) has found about 89 percent graduate from East Anglia University plausibly concerning on how to obtain a capital to start-up the business.

From the above literature, the researcher will identify does micro level is a barrier of students to start-up the business inside the campus.

\section{Methodology}

\subsection{Research Design}

Research design provides the glue that holds the research project together. A design is used to structure the research, to show how all of the major parts of the research project -- the samples or groups, measures, treatments or programs, and methods of assignment -- work together to try to address the central research questions. In this study, both descriptive and experimental studies were used.

\subsection{Unit of Analysis}

One of the most important ideas in a research project is the unit of analysis. In this study, the units of analysis are higher public institutions students in northern region. The students are independent of each other, so the student is the unit of analysis.

\subsection{Pilot Study}

A pilot study is an initial run-through of the procedures to be used in an investigation; it involves selecting a few people and trying out the study on them. It is possible to save time, and in some cases, money, by identifying any flaws in the procedures designed by the researcher. A number of 50 respondents will be chosen in the pilot study. This enables the researcher to establish how easily questions are understood, how long the questionnaire takes to complete, etc. A little time invested early on in the design of a study or questionnaire pays off in terms of the main study being well thought through.

\subsection{Theoretical Framework}

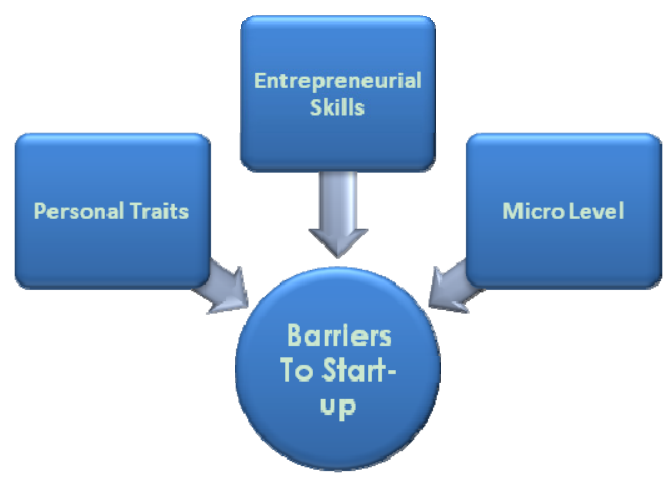

Figure 1. 


\subsection{Sampling Techniques}

The sample respondents will be chosen using multistage sampling. Multistage sampling refers to sampling plans where the sampling is carried out in stages using smaller and smaller sampling units at each stage. This study is conducted using three stage sampling. In the first stage, public universities were selected at random and without replacement from the list of all six public universities in the northern states of Malaysia. In the second stage, the programme were identified and selected at random and cluster sampling was employed to select the class. Questionnaire will be distributed to the whole class being selected.

The target population of this study is all students in higher institutions in northern region. The higher public institutions include UiTM Kedah, UiTM Pulau Pinang, UiTM Perak, UiTM Perlis, USM, UNIMAP, Universiti Utara Malaysia (UUM). The sample of students will be selected at random from the above institution using multistage sampling.

\section{Analysis}

\subsection{Profile of Respondents}

The respondents of this study consisted of 303 students attending public university in the northern states of Malaysia. The students are from various fields of studies, namely Accounting, Public Administration, Business Studies and Engineering.

Table 1. Demographic profile of respondents

\begin{tabular}{cccc}
\hline & & Frequency (n) & Percent (\%) \\
\hline \multirow{2}{*}{ University } & UNIMAP & 50 & 16.3 \\
& UUM & 62 & 20.3 \\
& UiTM Perlis & 36 & 11.8 \\
& USM & 53 & 17.3 \\
& UiTM P.Pinang & 57 & 18.6 \\
Gender & UiTM Kedah & 15 & 4.9 \\
& UiTM Perak & 33 & 10.8 \\
& Male & 98 & 32.2 \\
& Female & 206 & 67.8 \\
Monthly Household Income (RM) & $<$ RM1,000 & 123 & 41.1 \\
& RM1,000 - RM2,000 & 85 & 28.4 \\
& RM2,000 - <RM3,000 & 39 & 13.0 \\
& RM3,000 - $<$ RM4,000 & 20 & 6.7 \\
& RM4,000 - RM5,000 & 19 & 6.4 \\
& $>$ RM5,000 & 13 & 4.7 \\
Family member(s) involvement in business & Yes & 140 & 46.2 \\
& No & 163 & 53.8 \\
& Yes & 170 & 56.1 \\
Have you start up the business? & No & 133 & 43.9 \\
& Yes & 56 & 32.9 \\
& No & 114 & 67.1 \\
\hline
\end{tabular}

Table 1 shows the demographic profile of respondents in this study. From the table below, we know that majority of the respondents are female (67.8 percent) and comes from family who earns less than RM1, 000 per month (41.1 percent). 53.8 percent of the respondents have family member(s) who involved in the business. In the past 6 months, 56.1 percent of the respondents plan to do business. However, 67.1 percent of the respondents who plan to do business do not proceed. This study attempted to understand the reasons behind this scenario. 


\subsection{Barriers to Start- Up}

\subsubsection{Personality Traits}

Table 2. Clustering of respondents by their personality traits

\begin{tabular}{|c|c|c|c|}
\hline \multicolumn{2}{|r|}{ Label } & 1 & 2 \\
\hline \multirow[t]{11}{*}{ Description } & Course & $\begin{array}{l}\text { Diploma and non-business } \\
\text { bachelor }\end{array}$ & Business Oriented (Bachelor) \\
\hline & Gender & Male & Female \\
\hline & University & UUM, USM, UNIMAP & $\begin{array}{c}\text { UiTM P.Pinang, Kedah, Perak and } \\
\text { Perlis }\end{array}$ \\
\hline & Family involvement & Yes & No \\
\hline & Plan to do business & Yes & No \\
\hline & $\begin{array}{l}\text { Have started the } \\
\text { business }\end{array}$ & No & No \\
\hline & $\begin{array}{l}\text { Monthly household } \\
\text { income }\end{array}$ & $<$ RM5,000 & $>$ RM5,000 \\
\hline & \multirow[t]{4}{*}{ Features } & problem_solvin & problem_so \\
\hline & & self confidence & self_confidence \\
\hline & & info see & info_seeking \\
\hline & & initiatives & initiatives \\
\hline
\end{tabular}

Table 2 shows the clustering of the respondents by their personality traits. Respondents are clustered into two groups where we can clearly see that diploma and non-business course are clustered into one group while a business-oriented Bachelor course is in the other group. There are four items of personality traits under study i.e. problem solving, self-confidence, information seeking and initiatives and the important of each item are estimated.

Both groups consider the same weight of important on the items. Problem solving skills is regarded as the most important items in personality traits followed by self confidence, information seeking and self-initiative. However, in terms of the agreement on the items, we can see some opposition where the students in UiTM universities are more positive on each of the items under study.

Although the agreement of each items under study is low for the other universities, they got the plan to do the business. It may spark from the family involvement in the business. However, they do not start the business yet. One of the possible factors that might contribute to this scenario is lower monthly household income $(<\mathrm{RM} 5,000)$.

\subsubsection{Entrepreneurial Skills}

In this study, entrepreneurial skills are measured by two items; time management and knowledge skills. Table 3 shows the clustering of respondents by their entrepreneurial skill measured by the two items. As for personality traits, the respondents also clustered into two groups and interesting findings were shown. 
Table 3. Clustering of respondents by their entrepreneurial skills



In Table 3, UiTM students are showing better agreement on personality behaviour. However, they show less agreement on the entrepreneurial skills. Most of the respondents in this group (Group 2) come from Management courses (Bachelor in Accounting, Bachelor in Human Resource, and Bachelor in Office System Management etc). Universiti Utara Malaysia (UUM) and Universiti Sains Malaysia students' show better agreement on entrepreneurial skills where they are expose to the family involvement in business and already started their own business.

\subsubsection{Micro Level}

Micro-level factors that might hinder students to start-up the business are consisting of opportunity identification, motivation, resources/financing strategies and performance. In this study, only two items in micro level are studied; opportunity identification and financial. 
Table 4. Clustering of respondents by micro level

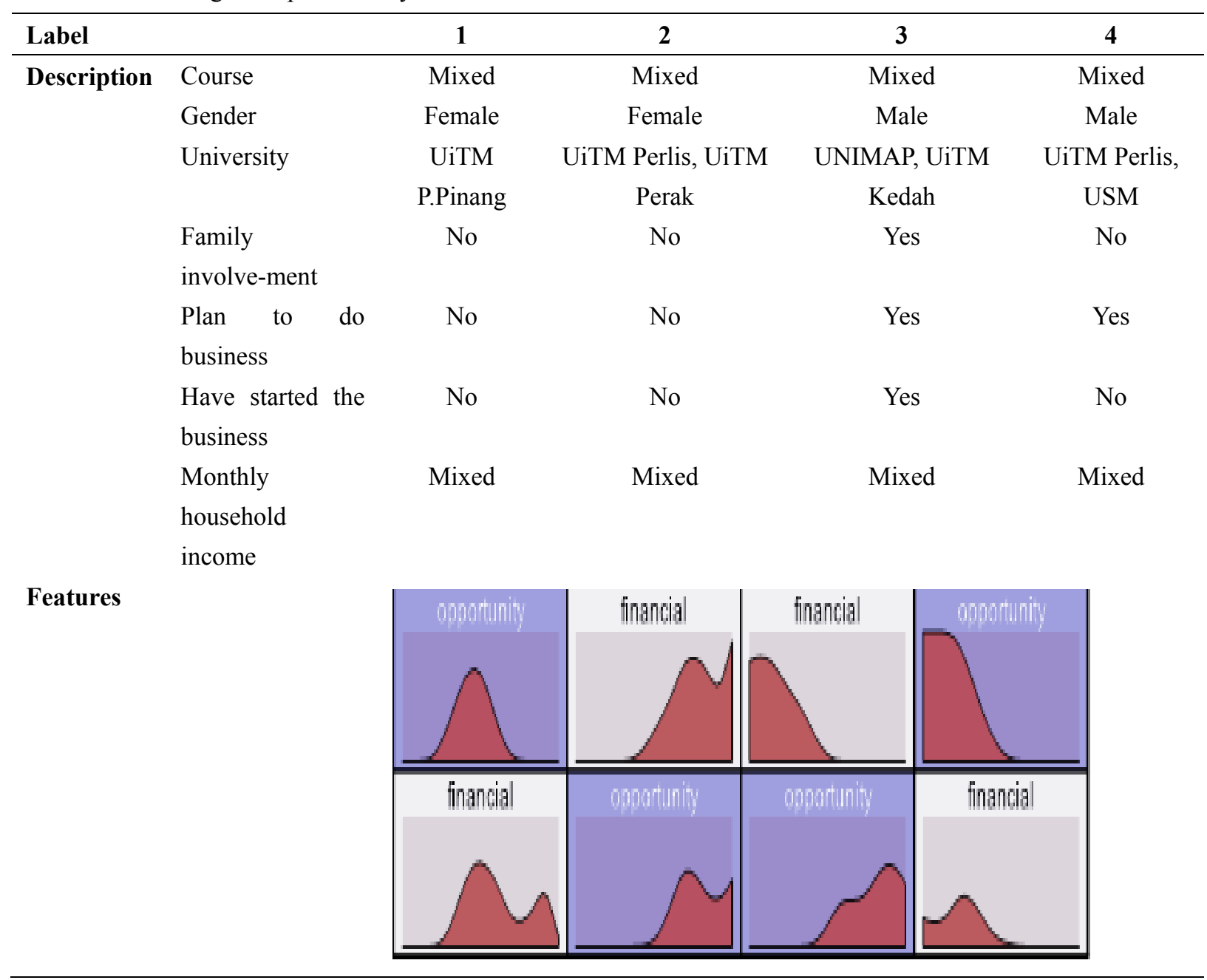

Table 4 shows the clustering of respondents by micro level factor. In general, respondents are clustered into four different groups. It is interesting to note that those in Group 2 who do not have any plan to do business sees that the financial barrier is the most important factor and have better agreement on this item. However, for those in Group 3 , they also see the financial barrier the most important factor but have the contrary agreement. It may due to the exposure received by doing business and also the family involvement.

For respondents in Group 1, they see the important of opportunity in the business and have a balance agreement on that. However, those in Group 4 who also have the same characteristics as Group 1, show less agreement on the opportunity available around them.

\section{Discussion}

Entrepreneurlism is becoming an important concept to academic world. The educational institutions are recognizing their ability to provide a useful and relevant learning experience and have started to change the way they operate to produce a good and capable young entrepreneurs of the future and strengthening the economy of the coutry. The encouragement among lecturers necessarily is needed by students to motivate them implementing the business.

The findings indicates that the problem solving skills is regarded as the most important items in personality traits followed by self confidence, information seeking and self-initiative as a barriers to start-up the business. Proper entrepreneurship education should be given to the students and strengthen their personality traits to make them to be a better entrepreneurs. The educational institutions should take an initiative by exposing students on how to start up the business and experiencing the challenges of entrepreneurial environment by developing a practical and realistic class projects during learning sessions, accepting responsibility for their behaviour during the class, 
performing tasks completely and effectively, accepting and utilize suggestions to improve performance, demonstrating positives leadership qualities and analyzing problems with appropriate solutions.

The entrepreneur's success in developing the business to survive and grow in the early years depends on the identification of crucial entrepreneurial skills. The survey indicates the failure of utilizing the entrepreneurship skills such as time management and knowledge skills as a factors influencing to start -up the business. The students should be trained using a proper time management techniques including scheduling their planning day-to-day activities according the priority to achieve their business goals. The students also have to be encouraged to develop their knowledge skills in order to find good information sources and knowledge application to survive in the markets. Many educational institutions have broadened their mission beyond education and research by knowledge sharing and transfer among experience entrepreneurs trainer's in entrepreneurship centre. Tunas Mekar programme, that developed by the UiTM as a training centre for the young graduates entrepreneur to learn the theoretical and practical knowledge regarding the entrepreneurship and how to start-up the business.

The financial are the most micro-level factors that might hinder students to start-up the business have studied in this survey. Limited access to funding is one of the key problems discouraging people from being enterprising. Moreover, a strict policy for entrepreneurs to get a financial grant from the bank as a capital to start a business hinders their development. While some of the students that have business funds having a difficulty in managing and planning their financial. The government has taken initiatives by providing various types of funding that available in the form of grants, loans and incentives for various industrial sectors and enterprises. The financing schemes such as Bank Negara Malaysia New Entrepreneurs Fund, MARA Business Financing for Bumiputera, Franchise Investment and Financing Schemes, Dana Projek Usahawan Bumiputera dalam Bidang Peruncitan (PROSPER) and MATRADE Market Development Fund are available to help the future entrepreneurs to start up their businesses.

\section{Acknowledgment}

This study is funded by Excellent Fund Grant by Universiti Teknologi Mara (UiTM) under Code No 600-RMI/SSP/DANA 5/3/Dsp (93/2011). The authors would please to thank UiTM for their financial support. In particular, the authors would also like to extent their deep gratitude and acknowledgment to all the students and lecturers as a token of their valuable support in distributing and collecting the data.

\section{References}

Buang, N. A., \& Murni, I. (2006). Prinsip-prinsip kewirausahaan: konsep, teori dan model-model pembentukan wirausahawan. UKM: Fakulti Pendidikan.

Cunningham, J. B. (1996). Entrepreneurial skills. In D. L. A. Meng, \& T. W. Liang (Eds.), Entrepreneurs, entrepreneurship \& enterprising culture (pp. 57-93). Singapore: Addison-Wesley Publishing Company, Inc.

Cunningham, J. B., \& Lischeron, J. (1991). Defining entrepreneurship. Journal of Small Business Management, 29(1), 45-59.

Daud, S., Abidin, N., Sapuan, N. M., \& Rajadurai, J. (2011). Enhancing university business curriculum using an importance-performance approach: A case study of the business management faculty of a university in Malaysia. International Journal of Educational Management, 25(6), 545-569. http://dx.doi.org/10.1108/09513541111159059

Giocamin, O., Janssen, F., Pruett, M., Shinnar, S. R., Llopis, F., \& Toney, B. (2010). Entrepreneurial intentions, motivations and barriers: Differences among American, Asian and European students. International Entrepreneurship and Management Journal.

Gurol, Y., \& Atsan, N. (2006). Entrepreneurial characteristics amongst university students: some insights for entrepreneurship education and training in Turkey. Education and Training, 48(1), 25-38. http://dx.doi.org/10.1108/00400910610645716

Henderson, R., \& Robertson, M. (1999). Who wants to be an entrepreneur? Young adult attitudes to entrepreneurship as a career. Education and Training, 41(5), 236-245. http://dx.doi.org/10.1108/00400919910279973

Jamali (2009). Constraints and opportunities facing women entrepreneurs in developing countries: A relational perspective. Gender in Management: An International Journal, 24(4), 232-251. http://dx.doi.org/10.1108/17542410910961532

Katz, J. A. (2003). The chronology and intellectual trajectory of American entrepreneurship education. Journal 
of Business Venturing, 18(2), 283-300. http://dx.doi.org/10.1016/S0883-9026(02)00098-8

Kinicki, A., \& Williams, B. K. (2003). Management: A Practical Introduction. California: McGraw-Hill.

Kolvereid, L., \& Moen, O. (1997). Entrepreneurship among business graduates: does a major in entrepreneurship make a difference? Journal of European Industrial Training, 21(4), 154-160. http://dx.doi.org/10.1108/03090599710171404

Linan, F. (2008). Skill and value perception: how they affect entrepreneurial attentions? International Entrepreneurship and Management Journal.

Louw, L., Van Eeden, S. M., Bosch, J. K., \& Venter, D. J. L. (2003). Entrepreneurial traits of undergraduate students at selected South African tertiary institutions. International Journal of Entrepreneurial Behavior \& Research, 9(1), 5-26. http://dx.doi.org/10.1108/13552550310461027

Lussier, R. N. (2006). Management fundamentals: concepts, applications, skill development (3rd ed.). USA: Thomson South-Western.

McLarty, R. (2005). Entrepreneurship among graduates: Towards a measured response. Journal of Management Development, 24(3), 223-238. http://dx.doi.org/10.1108/02621710510584044

Mun, L. Y. (2012, July 7). Jobless rate down to 2.9\%. Retrieved 2012, July 12, from http://www.thestar.com.my

Omar, W. L. O. W., \& Mohamed, S. (2006). Memperkasakan usahawan: panduan lengkap pengurusan perniagaan dan penjanaan usahawan. Kuala Lumpur: Utusan Publications \& Distributors Sdn. Bhd.

Robertson, M., Collins, A., Medeira, N., \& Slater, J. (2003). Barriers to start up and their effect on aspirant entrepreneurs. Education and Training, 45(6), 308-316. http://dx.doi.org/10.1108/00400910310495950

Robinson, P., \& Hayes, M. (1991). Entrepreneurship education in America's major universities. Entrepreneurship Theory \& Practice, 15(3), 41-52.

Ronstadt, R. (1987). The educated entrepreneurs: a new era of entrepreneurial education is beginning. American Journal of Small Business, 11(4), 37-53.

Sandhu, S. M., Sidique, F. S., \& Riaz, S. (2011). Entrepreneurship barriers and entrepreneurial inclination among Malaysian postgraduate students. International Journal of Entrepreneurial Behaviour \& Research, 17(4), 428-449. http://dx.doi.org/10.1108/13552551111139656

Sexton, D. L., \& Upton, N. E. (1984). Entrepreneurship education: suggestions for increasing effectiveness. Journal of Small Business Management, 22(4), 18-25.

Shane, S. (2003). A general theory of entrepreneurship: The individual-opportunity Nexus. United Kingdom: Edward Elgar Publishing Limited.

Smith, K., \& Beasley, M. (2011). Graduate entrepreneurs: intentions, barriers and solutions. Education \& Training, 53(8-9), 722-740. http://dx.doi.org/10.1108/00400911111185044

Solomon, G. T., Duffy, S., \& Tarabishy, A. (2002). The state of entrepreneurship education in the United States: a nationwide survey and analysis. International Journal of Entrepreneurship Education, 1(1), 65-86.

Yusof, A. A., \& Yusof, Z. (2004). Prinsip keusahawanan (2nd ed.). Selangor: Prentice Hall.

\section{Copyrights}

Copyright for this article is retained by the author(s), with first publication rights granted to the journal.

This is an open-access article distributed under the terms and conditions of the Creative Commons Attribution license (http://creativecommons.org/licenses/by/3.0/). 